\title{
Uncovering benefits and risks of integrated product service offerings: Using a case of technology encapsulation
}

\author{
Tomohiko Sakao, Anna Öhrwall Rönnbäck and Gunilla Ölundh Sandström
}

\section{Linköping University Post Print}

\section{Tweet}

N.B.: When citing this work, cite the original article.

The original publication is available at www.springerlink.com:

Tomohiko Sakao, Anna Öhrwall Rönnbäck and Gunilla Ölundh Sandström, Uncovering benefits and risks of integrated product service offerings: Using a case of technology encapsulation, 2013, Journal of Systems Science and Systems Engineering.

http://dx.doi.org/10.1007/s11518-013-5233-6

Copyright: Springer Verlag (Germany)

http://www.springerlink.com/?MUD=MP

Postprint available at: Linköping University Electronic Press

http://urn.kb.se/resolve?urn=urn:nbn:se:liu:diva-102429 


\title{
UNCOVERING BENEFITS AND RISKS OF INTEGRATED PRODUCT SERVICE OFFERINGS - USING A CASE OF TECHNOLOGY ENCAPSULATION*
}

\author{
Tomohiko Sakao ${ }^{1}$, Anna Öhrwall Rönnbäck², Gunilla Ölundh Sandström ${ }^{3}$ \\ ${ }^{1}$ Division of Environmental Technology and Management, Department of Management and Engineering, \\ Linköping University, Sweden \\ tomohiko.sakao@liu.se $(\bowtie)$ \\ ${ }^{2}$ Division of Industrial Economics, Department of Management and Engineering, Linköping University, \\ Sweden \\ anna.ohrwall.ronnback@liu.se \\ ${ }^{3}$ Unit of Integrated Product Development, Department of Machine Design, KTH Royal Institute of \\ Technology, Sweden. \\ gunillao@kth.se
}

\begin{abstract}
The objective of this article is to uncover benefits and risks of Integrated Product Service Offering (IPSO) in a systematic manner. To do so, it adopts an explorative longitudinal in-depth case study (development of an IPSO based on a new technology) and adds insights to the existing literature. The article first proposes a theoretical and generic framework termed the PCP (Provider - Customer Product) triangle with associated information flow and uncertainty. Second, various types of benefits and risks are presented based on the framework. Among others, the benefit of keeping IPR (Intellectual Property Rights) with the provider and the risk of regulation change are new findings from the case study. In addition, the case study reveals that IPSO is regarded as a positive contributor to innovation. Applying the framework and classification of benefits and risks as norms to other cases has yet to be done for verification. However, the framework contributes scientifically to a better understanding of the benefits and risks of IPSO. In addition, this framework is advantageous with its easiness to understand, which contributes practically to the dissemination of IPSO insight to industry. Keywords: Product/Service System (PSS), new technology, Intellectual Property Right (IPR), time to market, innovation, uncertainty
\end{abstract}

\footnotetext{
${ }^{*}$ This research was partially supported by the project Management of Innovation Processes for Business Driven Networks, funded by VINNOVA (The Swedish Governmental Agency for Innovation Systems).
}

(c) Systems Engineering Society of China and Springer-Verlag Berlin Heidelberg 2011 


\section{Introduction}

In the last decade, interest in integration of services and physical products in the manufacturing industry has grown, both from the viewpoints of theory and practice (Mont 2002, Oliva and Kallenberg 2003, Alonso-Rasgado, Thompson, et al. 2004, Meier, Roy, et al. 2010). This integration is even referred to as the next industrial revolution (Tien 2012). Services here include e.g. monitoring, inspection, operation, maintenance, repair, upgrade, overhaul, take-back, training, and consultation. Most of the literature so far has emphasized new opportunities with this integration (e.g. (Tukker and Tischner 2006)), and suggested work methods and strategies for the so-called Product/Service Systems (PSS) (e.g. (Sakao and Shimomura 2007, Isaksson, Larsson, et al. 2009)). However, they tend to be generic in terms of obtained insights applicable to a wide range of sectors without specifying delimitations or conditions, mainly providing results on the positive aspects. A systematic classification of the benefits is unavailable.

It is relatively recent that literature reports insights of the other side of this subject: difficulties, uncertainties, and risks for such integration (Hypko, Tilebein, et al. 2010, Ng and Nudurupati 2010, Nordin, Kindström, et al. 2011). In addition, recently some light has been shed on characteristics of products suitable for integration (Lay, Copani, et al. 2010); for instance, on such integration, innovativeness of products has been argued to have positive influences. The reasons behind it is that if users are unfamiliar with the products they might be afraid of technical failures and thus appreciate support service and guarantee of resulting functionality when in use. Findings from these studies suggest that not every physical product will necessarily gain benefits in the same way from integration with services. Such delimitations and negative aspects are critical in business, and should be investigated more.

In fact, most previous research in the field is based on evidence from servicification of the traditional goods-oriented manufacturing industry (e.g. (Oliva and Kallenberg 2003, Alonso-Rasgado, Thompson, et al. 2004, Windahl, Andersson, et al. 2004, Gebauer, Krempl, et al. 2008, Isaksson, Larsson, et al. 2009, Kindström and Kowalkowski 2009)). Research on PSS based on technological innovation is limited. For example, the Integrated Product Service Offering (IPSO) business model has potential for better control of a new technology for the providing party (Lindahl, Sakao, et al. 2009). However, little insight is available on how products based on innovative technologies, which often need protection for their intellectual property rights (IPR), can take advantage of IPSO. Note that the term IPSO is used in this article rather than PSS in order to emphasize the integrated offering aspect. If the provider takes care of e.g. maintenance and operations of the equipment, the core technology could be encapsulated and hidden. Especially as innovation tends to be more often developed in close collaboration with customers and other external parties, as suggested by e.g. (von Hippel and Katz 2002, Chesbrough 2003), it is interesting to investigate IPSO as a business model to protect IPR.

The objective of this article is to uncover benefits and risks of IPSO in a systematic manner, in particular, for a manufacturer of a 
Sakao et al.: Uncovering Benefits and Risks of Integrated Product Service Offerings - Using a Case of Technology Encapsulation

highly innovative product. To do so, the article is based on an explorative longitudinal in-depth case study: the development of a particular IPSO based on a new technology for a new market, developed on a customer site.

The remainder of the article consists of the following. Section 2 describes current scientific understanding of service integration based on a literature review. Next, Section 3 explains the research method of the paper and presents the result of the case study. Following that, Section 4 analyses the case from the perspective of IPSO benefits and from a risk perspective. Finally, Section 5 discusses the results and concludes the paper.

\section{Integration of services into manufacturing companies' product offerings - identifying two research gaps}

This section shows different research streams for the area of goods and service integration, and highlights some research gaps. Service integration is not totally new, since a performance-based contract was raised as a research target as early as the 1960s in defence contracting according to e.g. (Hypko, Tilebein, et al. 2010). The research for this subject has grown significantly, especially during the last decade, and the research is performed and presented in different research disciplines. This creates a large diversion in the terminologies used, but according to (Sakao, Ölundh Sandström, et al. 2009), two main research streams can be recognized to originate from a service and marketing perspective (e.g. service-dominant logic (SDL) in (Vargo and Lusch 2004)) and from a sustainability perspective (e.g. ecodesign in (Tukker and Tischner 2006)). In addition to these, another growing group is approaching from an engineering perspective (e.g. (Alonso-Rasgado, Thompson, et al. 2004)).

In service and marketing research, business logic, value-creating processes and contract types are much debated. Among others, according to the trend of giving importance to service in general, SDL (Vargo and Lusch 2004) introduces a way of regarding the physical parts and the technology of a product as service carriers. In addition, to have a close relationship with customers is highly recommended in order to really understand customer needs and have the view that services are coproduced with the customer (e.g. (Windahl and Lakemond 2006)). The closer relationship is implied as illustrated in Figure 1; as compared to product sales (a), the IPSO provider (b) gets closer to the customer as a result of getting closer to the product. Furthermore, how companies make their transition from product provider to service provider also has been getting attention by uncovering different challenges about capabilities (Oliva and Kallenberg 2003, Davies 2004, Gebauer, Fleisch, et al. 2005, Teece 2007, Fischer, Gebauer, et al. 2010).

In the research stream from an environmental sustainability perspective, the focus is more on analysis (and less on synthesis) of PSS (Goedkoop, Halen, et al. 1999, Mont 2002, Manzini and Vezzoli 2003, Tukker 2004, Tukker and Tischner 2006, Sakao and Shimomura 2007). The most promising type from the environmental aspect is argued to be the result-oriented service promising a certain result wanted by a customer (Tukker 2004), 
where the ownership of the equipment and the control of the operation are typically not transferred to the user as in Figure 1 (b). The customers' interests do not lie in service per se but rather in how to innovate and co-create value in new ways, in order to achieve environmental and economic benefits through addressing material/substance management (e.g. (Mont, Singhal, et al. 2006)), user behaviour (e.g. (Meijkamp 2000)), etc. from the life cycle perspective.

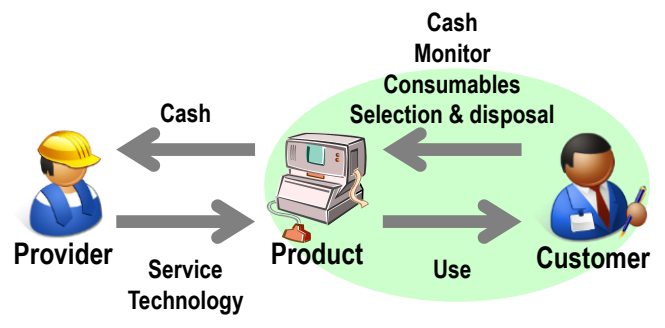

(a) Product sales

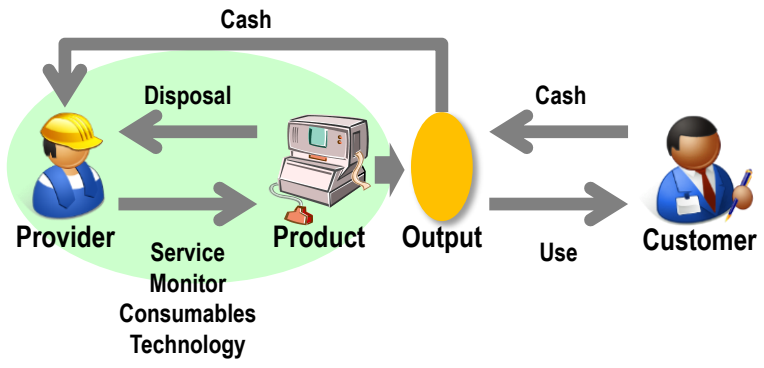

(b) IPSO

Figure 1 Differences between (a) product sales and (b) IPSO (adapted from (Baines, Lightfoot, et al. 2007))

Motivated by the increasing importance and opportunities of services for manufacturers (Isaksson, Larsson, et al. 2009, Meier, Roy, et al. 2010), the engineering approach focuses on the development process aiming at providing guidelines or tools for both service and product developers putting emphasis on the integration aspects of the product and service (e.g. (Alonso-Rasgado, Thompson, et al. 2004, Aurich, Fuchs, et al. 2006)). Even computer-aided design software (Hara, Arai, et al. 2009, Sakao, Shimomura, et al. 2009) to support modelling and development in general has been proposed.
Analysing the existing literature reveals a need for research of unexplored issues as follows. First, the insights from most of the existing literature reviewed in the three groups above have a generic nature. Namely, it appears that most of the knowledge can be applied to a broad range of product types, with the risk that delimitation regarding the product types has not been fully understood. The discussion is starting to become more specific, for instance, in searching for what types of offerings are better suited for an integrated offering, such as innovative products (Lay, Copani, et al. 2010). The IPSO business model may enable the 
Sakao et al.: Uncovering Benefits and Risks of Integrated Product Service Offerings - Using a Case of Technology Encapsulation

technology provider to take care of the maintenance and operations of the products, instead of having to transfer know-how about built-in product technologies to the users. Therefore, the IPSO's positive influences on the possibility to encapsulate secret technology in the product are expected. Nevertheless, little insight is available from existing literature on this important issue for a wide range of manufacturers. Thus, it is of interest to further investigate in the products with technologies that need to be taken special care of by providers, i.e. controlled (see (Håkansson and Laage-Hellman 1984)).

Second, most of the literature so far has emphasized the positive opportunities of integration of goods and services, especially as an eye-opener for manufacturing firms in traditional industries. Literature has only recently begun to report about the other side of this subject - its difficulties, uncertainties, and risks (Nordin, Kindström, et al. 2011). For instance, $\mathrm{Ng}$ et al. (2010) explored, in the defence industry, challenges and risks of implementing outcome-based contracts, such as complexity and unpredictability of costs, and dependability on customers in delivering the service. Nordin et al. (2011) point at operative, strategic, and financial risks linked to the customization, bundling, and range of the integrated offering when services are added to the manufacturing company's goods offering. Sawhney et al. (2004) proposed another classification of risks with servitization from the viewpoint of consequence: market risk (will customers come?), capability risk (can we do it?), and financial risk (can we make money?). However, the framework for different types of risks based on the sources of uncertainty is missing, even though it will be more useful in mitigating (or managing) risks in a fundamental and proactive manner. It is of interest to look further into this when it comes to technology innovation development, which is largely characterised by high uncertainty.

\section{Encapsulating technology by IPSO - a case study}

\subsection{Method}

The article is based on an exploratory longitudinal in-depth case study of the development of a plant based on a new technology for a new market, developed on a customer site, with IPSO. The case study method was chosen to study the benefits and risks of IPSO for a highly innovative product, giving the possibility to grasp the complexity of this phenomenon so difficult to demarcate (Eisenhardt 1989, Yin 1989). The opportunity was given to follow the case in real-time over several years (2007-2012), complemented with a retrospect study through interviews and secondary data such as press releases for the years prior to 2007. The analysis of the case can be characterized as systematically going back and forth between the case data and the literature, i.e. systematically combining the two in a process to expand understanding of theory as well as of the empirical phenomena.

\subsection{Case study}

The case was carefully selected (theoretical sampling suggested by e.g. (Eisenhardt and Graebner 2007)) to shed light on the two sides of the coin: advantages of encapsulation of 
technology, as well as risks with uncertainty about both a new technology and a new market. The case was selected together with a financial supporting body (a Development Finance Institution (DFI)) with in-depth confidential access to business initiatives fitting the case selection criteria (complex technology and entering unknown markets). The selection among similar available cases was made based on the criteria of the business model, IPSO, to encapsulate technology and provide the possibility to carry out interviews and follow the case in real-time. It was previously reported at a mid-term stage in 2010 (Öhrwall Rönnbäck, Janhager, et al. 2010).

The studied case has its basis in a joint venture (JV) of different companies together with the DFI, all based in Sweden (except for the local customer contact in China). The JV was suggested to the partner companies by the DFI as a way to protect the potential business based on a jointly developed technology solution for a certain industry sector. The partners in the JV were (1) the coordinator company, (2) the core technology provider, (3) the operator, (4) the local customer contact company (this had to quit due to Chinese rules of ownership in a foreign JV), and (5) the financier, i.e. the DFI. The operational organization of the JV was limited in size, acted mostly as a shopwindow, and consisted of representatives from the partner firms. They all had their respective interests, and different competencies and strengths. The DFI played somewhat a leadership role, informally, for this process, which continued throughout the development process. However, the DFI tried to keep out of technical discussion as much as possible. At the end, the DFI, the coordinator, and the operator decided to put together a contract, where they discussed agreements for the JV about dealing with clients and selling offerings, payment processes, etc. It was decided that all the partners should be treated equally, though they had different competencies, and amount of shares.

The purpose of the JV was thus to develop and construct a complete facility for the pulp and paper industry, and utilize a new and innovative technology enabling a more environmentally-friendly production process. To approach the new market in China, the JV started a subsidiary there with the objective to construct and run the facility plant at customers' sites locally. The JV's offering was provided in the form of an IPSO. Both the technology and the service-based business model were new to the provider and the customer in the studied case. The targeted market was new to the provider, both in terms of geography and industrial sector. Note that the JV was the unit of analysis in this case study and regarded as a single organization. I.e. this study is not a multiple case study.

Eight interviews of between 60-90 minutes each were conducted (see Table 1), with the interviewees representing key persons in each individual company in the joint venture (except for the sixth), with follow-up interviews with three of the key persons one to two years after the initial interviews. Continuously updated information was gathered from contact persons at the DFI in the JV. The interviews were recorded, transcribed and analysed. The results of the interviews are summarized in Section 3.3. 
Sakao et al.: Uncovering Benefits and Risks of Integrated Product Service Offerings - Using a Case of Technology Encapsulation

Table 1 Overview of the studied companies and interviewees for the case study

\begin{tabular}{|c|c|c|c|}
\hline Company & Major business and role in the JV & Size $e^{* *}$ & $\begin{array}{l}\text { Number of } \\
\text { Interviewees }\end{array}$ \\
\hline 1-Coordinator & $\begin{array}{l}\text { - Coordinates the network. } \\
\text { - Main shareholder of the joint venture company. } \\
\text { - Leads projects. } \\
\text { - Owns the core patents. } \\
\text { - Has the knowledge of the process in the plant. }\end{array}$ & $\overline{\mathrm{L}}$ & $\begin{array}{c}2 \\
\text { (one is the } \\
\text { inventor) }\end{array}$ \\
\hline $\begin{array}{l}\text { 2-Core technology } \\
\text { provider }\end{array}$ & $\begin{array}{l}\text { - Develops and delivers the core technology to build the plant. } \\
\text { - Builds the plant in cooperation with the client in China. }\end{array}$ & $\mathrm{S}$ & 3 \\
\hline 3-Operator & $\begin{array}{l}\text { - Operates the plant in China; the one with the client contacts. } \\
\text { - Runs and manages the plant in China. } \\
\text { - Finds local customers in China. } \\
\text { - Locates the contractors who will build the plant in China in } \\
\text { cooperation with Company } 2 \text {. }\end{array}$ & $\mathrm{L}$ & 1 \\
\hline $\begin{array}{l}\text { 4-Local customer } \\
\text { contact }\end{array}$ & $\begin{array}{l}\text { - Provides local knowledge and advice in the water treatment } \\
\text { business in China. }\end{array}$ & $S$ & \\
\hline 5-Financier & $\begin{array}{l}\text { - State-owned Development Finance Institution (DFI). } \\
\text { - Provides venture capital and loans. } \\
\text { - Gives various supports such as lawyers' checking contracts. } \\
\text { - Gives advice on businesses and business models including } \\
\text { regulations at emerging markets. } \\
\text { - Provides opportunities to contact persons at high levels. }\end{array}$ & - & 1 \\
\hline $\begin{array}{l}\text { 6-Facilitator: } \\
\text { Swentec }\end{array}$ & $\begin{array}{l}\text { - Support business for Swedish companies with environmental } \\
\text { technology (not part of JV). }\end{array}$ & - & 1 \\
\hline
\end{tabular}

${ }^{*}$ Swedish Environmental Technology Council

${ }^{* * *}$ S: small, M: medium, and L: large company

\subsection{Key facts extracted from the interviews}

\subsubsection{The offered IPSO}

The JV provides an innovative total solution for recycling chemicals. They receive the chemical sludge from the customer, capture chemicals from the sludge that are one of the raw materials for the customer from the treatment plant, and then deliver it to the customer - i.e. selling the service of delivering the chemical substance (aluminium sulphate) instead of selling the equipment. In fact, according to the agreement, what they are supposed to deliver is the chemical substance, whether it is recycled or fresh. Therefore, if they do not gain sufficient volume and a good quality, the company has to supplement it from somewhere else.

The JV kept the ownership of the product (i.e. the plant) for this function and operated it based on the "build-own-operate (BOO)" model. This means that no instruction on the product is given to users - the customer knew the technology's principle but not its detailed information. This was according to a decision with Company 1's persistence to do so, due to the risk of the technology being copied. In other words, according to the two interviewees from 
Company 1 , the JV regarded their services as a way to decrease the risk of a technology being copied - the service was used to safeguard the invention. This was one of the two main intentions for providing service, actually being the first reason. Thus, the service provision preventing the technology copy could be regarded as a necessary condition in this case. Note that this technology is not yet commercialized to other customers, i.e. there is no competition on the market.

The second reason to provide service was to decrease the technical risk of the new offering, such as a malfunctioning of the physical product, according to the same interviewees from Company 1 . To be accurate, the extent of the consequence of the event is to be decreased, as the probability is not to be changed in this case. The packaged offering including the service is convenient and "risk free" for customers. Companies 1 and 2 regarded service as an enabler to early introduction of this technology to the market.

\subsubsection{The development process}

The development of the IPSO went through different stages as is often the case with a new technology: idea creation, small-scale tests, a pilot plant in Sweden, testing at a pilot plant in China, and testing at a full-scale plant in China. Below are some highlights.

Normally, companies develop, test and refine technologies before selling them to the market. Since the functionality of the technology had not been refined in real conditions at the point of sale, this gave the JV a chance to get an uncertain technology out to the first customer and refine it in real conditions. This was also a good opportunity for the JV to get data on the product in use. This was possible because of the service-based business model adopted. In this case, the JV wanted to collect data about how to control a membrane from their services to be able to apply the technology on the Swedish market.

Then, the JV signed a contract for the IPSO with a pulp and paper mill company in China. Soon after that, however, the CEO from the customer group asked for cancellation of this contract because they thought they might not get anything out of it. After some communication, this misunderstanding was quickly resolved and the same contract honoured.

\subsubsection{Business environment}

This offering has a positive ecological effect, since the recovered chemicals are returned to the chemical water treatment plant and the sludge volume is reduced. One of the reasons why JV targeted the Chinese market is because the regulation of the emission level in China is tougher; thus, this technology is more appreciated than in e.g. Sweden. The regulation about the sludge treatment is also expected to be strengthened in China, and if so, the technology will be appreciated even more there.

This ecological aspect also brought a threat as opposed to the opportunity described above. Due to rapid development of environmental regulations in China during the development, the legislation made the demands on the technology tougher, forcing the JV to change the specification of the IPSO. This aspect concerns the business environment (to be discussed in Section 4.3). 
Sakao et al.: Uncovering Benefits and Risks of Integrated Product Service Offerings - Using a Case of Technology Encapsulation

\section{Analysis of benefits and risks of IPSO}

\subsection{General framework proposed}

To analyse benefits and risks of an IPSO systematically, a framework was developed since the existing literature in this area is still limited. The main topic of this article is encapsulating technology, rather than keeping a physical product, which is about controlling access to information such as IPR. Therefore, the article introduces information flow among the concerned entities as a central parameter forming such a framework. It should be emphasized, however, that this adoption is not only created by the topic. The benefits of IPSO are argued in many cases to be related to access to information and uncertainty (lack of information), e.g. the key for a provider is to collect data about conditions of the product (e.g. (Alonso-Rasgado, Thompson, et al. 2004)). Therefore, this paper proposes the framework as a general way of classifying benefits of IPSO based on information and uncertainty.

Figure 2 depicts this theoretical framework as a tool to analyse risks and benefits of an IPSO termed the Provider-Customer-Product (PCP) triangle. The benefits, labelled as B1-6, are explained below in the next section. Here, the information addressed includes: physical conditions, behaviours, and functions of a product; signals taken in by a product; and operation and maintenance of a product. The flow of these types of information can be regarded as communication. From the viewpoint of effect, this flow can be classified into the mere moving of information, control of a recipient or even commitment to a recipient, through extending the notion of communication theorised as a process of expression, interaction, and influence in the socio-psychological discipline (Berger and Chaffee 1987). Using this framework, benefits and risks of an IPSO are explained. Tables 2 and 3 summarize the benefits and risks, respectively.

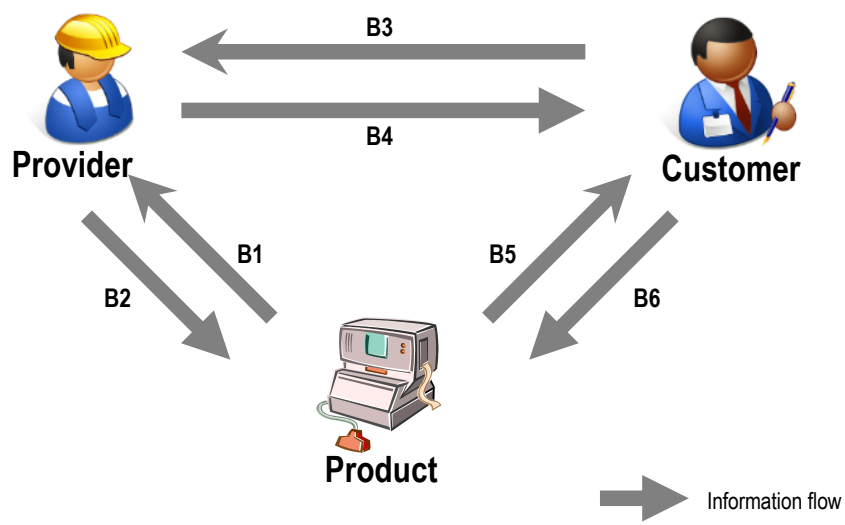

Figure 2 The PCP triangle - theoretical framework to analyse risks and benefits of an IPSO 


\subsection{Analysis of benefits of IPSO}

The benefits originating from the first four flows of information, i.e. from B1 to B4, are already reported in much of the literature. As seen in Table 2, the references listed are merely examples, meaning that other literature addressing the issues is available. For instance, IPSO may give a provider a better opportunity to obtain information from the use of the product (B1) (e.g. in-service knowledge is discussed in (Goh and McMahon 2009)) as well as, in the other direction, to control the product (B2) as reported in e.g. (Mont 2002). The information exchange between a provider and a customer is also addressed in much PSS literature. IPSO enables a provider to get more information from a customer via a closer relation (B3) (Mont 2002) and fulfil more commitment to a customer (B4) as reported in e.g. (Meier, Roy, et al. 2010).
In contrast, the information flow between a customer and a product is rarely discussed in the literature. However, as analysed in the case study in Section 3, changing how information is exchanged between these two entities was one of the reasons why IPSO was adopted in this business. Namely, the JV decided to adopt IPSO because they perceived it safer to keep the information or IPR about the technology within the control of the provider. The JV owned and operated the product, which means that the JV could use IPSO as an effective means to protect knowhow and technology by having IPSO as an appropriability regime strategy (Hurmelinna-Laukkanen and Puumalainen 2007). This case indicates the IPSO's power to decrease the amount of information flow from a product to a customer (B5), and as well as in the

Table 2 Summary of the benefits of an IPSO for a provider - findings from previous research and this article (Bold; finding on this article)

\begin{tabular}{|c|c|c|c|}
\hline & $\begin{array}{l}\text { Emerging benefits of an IPSO in } \\
\text { general }\end{array}$ & $\begin{array}{l}\text { Relevance with encapsulating a } \\
\text { technology }\end{array}$ & $\begin{array}{l}\text { Evidence from the } \\
\text { case }\end{array}$ \\
\hline B1 & $\begin{array}{l}\text { Getting in-service knowledge (Goh } \\
\text { and McMahon 2009) }\end{array}$ & Low & $\begin{array}{l}\text { Testing at the } \\
\text { customer's site was } \\
\text { possible due to IPSO. }\end{array}$ \\
\hline $\mathrm{B} 2$ & $\begin{array}{l}\text { Provider's better control of a product } \\
\text { (Mont 2002) }\end{array}$ & $\begin{array}{l}\text { High (especially in the case of a new } \\
\text { technology) } \\
\text { Shortening time to market - get first } \\
\text { customer's adoption of a new technology }\end{array}$ & $\begin{array}{l}\text { This was a reason for } \\
\text { IPSO. }\end{array}$ \\
\hline B3 & $\begin{array}{l}\text { Provider's getting more information } \\
\text { from a customer (Mont 2002) }\end{array}$ & Low & N.A. \\
\hline B4 & $\begin{array}{l}\text { Provider's closer commitment to a } \\
\text { customer (Windahl and Lakemond } \\
2006 \text { ) }\end{array}$ & $\begin{array}{l}\text { Low (encapsulation contributes to closer } \\
\text { commitment.) }\end{array}$ & N.A. \\
\hline B5 & $\begin{array}{l}\text { Keeping information away from } \\
\text { customer }\end{array}$ & High (for IPR of a technology) & Keeping IPR \\
\hline B6 & $\begin{array}{l}\text { Keeping less customer's } \\
\text { involvement in product operation }\end{array}$ & High (for IPR of a technology) & Keeping IPR \\
\hline
\end{tabular}


other direction (B6). This needs to be considered carefully especially in case that the customer is involved in the product development process. However, it does not mean that IPSO denies the customer involvement. The JV obtained information from the customer about the inputs into the offering in order to be able to fine tune the offering's processes and also information about the demanded quality of the outputs, while the JV could keep the knowledge of the process within itself.

It should be emphasized that the case study has provided the type B2 with another meaning - shortening time to market. Thanks to the time axis introduced and the uncertainty shown on the other axis, a benefit of an IPSO is clearly described in Figure 3. In general, the uncertainty of a product and a customer decreases along the development process of an IPSO or a product. However, a risk for technical malfunction becomes too high if the technology is introduced too early. Thus, there is a threshold on the uncertainty under which market launch becomes feasible. In the case of IPSE, a manufacturer can monitor and control its products better and even mitigate risks in a different way when ownership stays on the provider side, compared with a traditional product sales contract where the customer owns the product after purchase. This increase in the level of uncertainty allowed (from $u_{t}$ to $u_{i}$ ) creates a shortened time (from $t_{t}$ to $t_{i}$ ) to improve the quality of the technology. In the case study, this effect was indeed perceived as a reason for the company to include services in their offering.

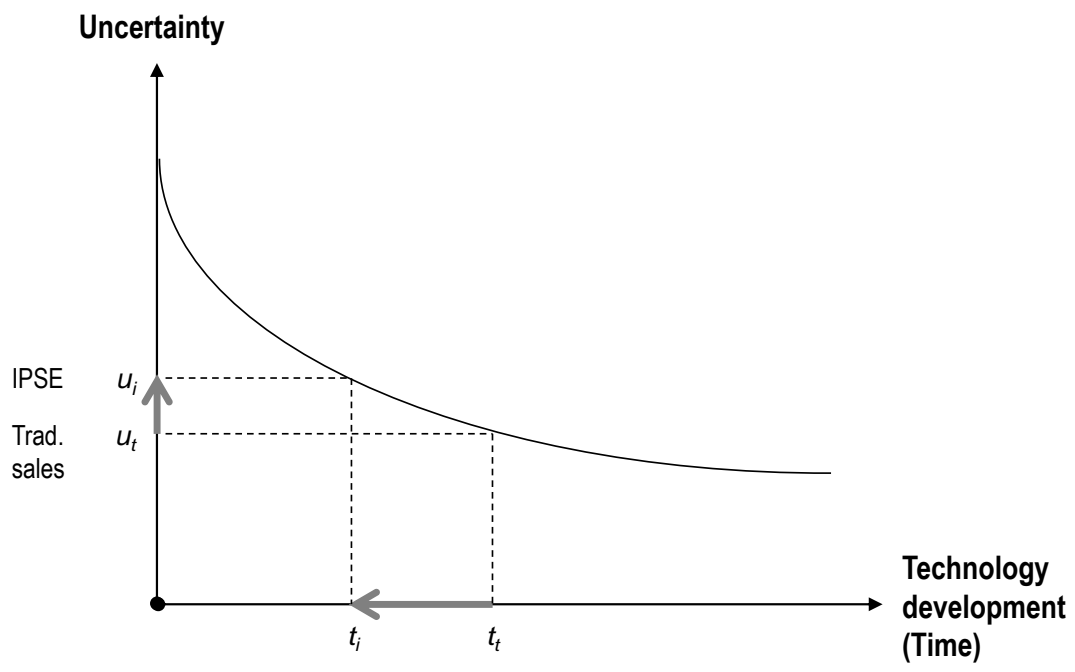

Figure 3 Effect of IPSE on time to market (possibility to reduce time in technology development projects) 


\subsection{Analysis of uncertainties and risks of IPSO}

To analyse the risks of an IPSO, it is fundamental to identify uncertainty rather than to begin with risks, because if the uncertainty becomes a risk it depends on conditions such as the business model. Uncertainty is defined here as lack of information, and is classified into two types, i.e. aleatory and epistemic uncertainty (Pender 2001). In an IPSO business, major sources of uncertainty can be classified into the physical product, the service, the customer (including the user), and the business environment. This is depicted in the PCP triangle shown in Figure 4, while Table 3 shows the proposed categorization. Note that the relevance with encapsulating a technology is not explicitly discussed in Table 3, as presentation of different types of risks per se is missing in the literature and thus demanded. The rest of this section first illustrates each uncertainty category and associated risks with references to the case presented in Section 3. Then, it discusses the relations of the risks to the benefits presented in Section 4.2.

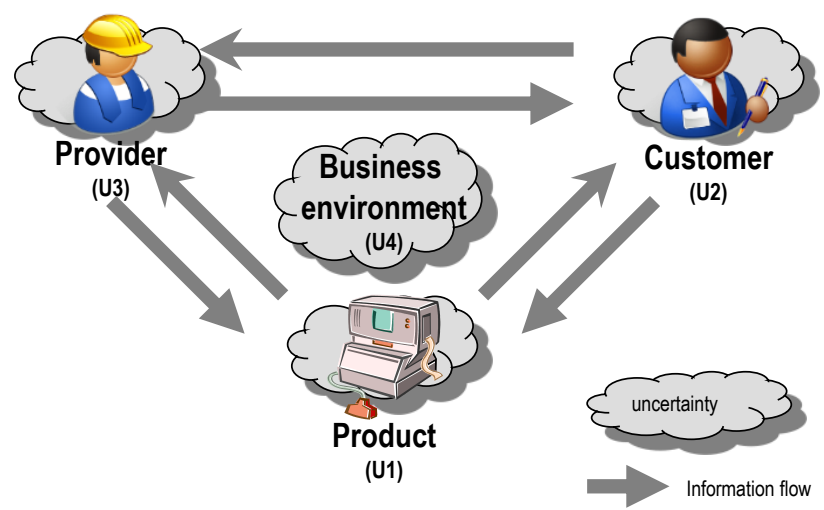

Figure 4 Uncertainty types depicted in the PCP triangle

Table 3 Summary of the risks of an IPSO for a provider - findings from previous research and this article (Bold; finding on this article)

\begin{tabular}{llll}
\hline & Uncertainty & Major emerging risks of IPSO & Evidence from the case \\
\hline \hline U1 & $\begin{array}{l}\text { Product function (e.g. (Meier, } \\
\text { Roy, et al. 2010)) }\end{array}$ & Product malfunction. & $\begin{array}{l}\text { The JV had recognized this } \\
\text { uncertainty and took this risk. } \\
\text { Balanced with B2. }\end{array}$ \\
\hline U2 & $\begin{array}{l}\text { Customer/user's commitment } \\
\text { and understanding (Ng and } \\
\text { Nudurupati 2010) }\end{array}$ & $\begin{array}{l}\text { Customer's failure in } \\
\text { commitment and understanding. }\end{array}$ & $\begin{array}{l}\text { Lack of understanding the } \\
\text { service-based business model. }\end{array}$ \\
\hline U3 & $\begin{array}{l}\text { Provider's activity (incl. } \\
\text { service) (Alonso-Rasgado, } \\
\text { Thompson, et al. 2004) }\end{array}$ & Provider's failure in commitment. & N.A. \\
\hline U4 & $\begin{array}{l}\text { Change of business } \\
\text { environments }\end{array}$ & $\begin{array}{l}\text { Prerequisites change in case of a } \\
\text { result-oriented contract. }\end{array}$ & Environmental regulation changed. \\
\hline
\end{tabular}


The type $\mathrm{U} 1$ is the uncertainty of product function. This has been one of the major issues in the engineering aspect of PSS as discussed in (Meier, Roy, et al. 2010). Major IPSO contents are physical products, maintenance, and repair (e.g. (Sakao, Napolitano, et al. 2008)). This also indicates that one of the reasons for providing IPSO is uncertainty of a product's function. If the contract is based on result or performance of the product function, this uncertainty becomes a risk for the provider. Note that the provider bears the costs for among other things time for repair engineers and spare parts, while they gain income as a result of the performance. In the studied case, the JV had recognized this uncertainty as well as the risk, and offered a result-oriented IPSO to the customer by taking this risk.

In general, providers benefit more from the earlier introduction of technologies to a market by the better window of opportunities (e.g. (Wheelwright and Clark 1992)). Thus, addressing trade-off between time to market and technical risk is an issue. IPSOs can bring a better way to address the issue, because a provider can release the product earlier (i.e. with a higher possibility of malfunction) with a plan to take care of potential malfunction with services. In the studied case, the time to market was indeed recognized as a benefit to the JV.

The type U2 is uncertainty deriving from a customer and a user. In an IPSO, value is often co-created (see co-creation discussed in the context of innovation in (Perks 2004, von Hippel 2005)), i.e. created together between a provider and a customer (and/or user), rather than delivered. This means that the involvement of a customer/user is needed in these cases and the provider is dependent on the customer/user ( $\mathrm{Ng}$ and Nudurupati 2010). In some cases, commitment by a customer/user, e.g. the daily check of a machine's condition, is a prerequisite for a contract (see an example in (Sakao, Paulsson, et al. 2011)). This commitment by a customer/user has uncertainty. This type of risk exists in the process of developing an IPSO as well. In other words, the provider and the customer may not reach agreement on a contract. This is especially relevant to the IPSO as it may be difficult for a customer to understand. In the studied case this became reality - the customer once stopped discussing the proposed IPSO due to a lack of understanding of its benefits for them.

This paragraph points out that the risk originating from $\mathrm{U} 2$ (the customer) has a trade-off relation with benefits in general, and is not grounded in the case. First, it concerns the control of product (B2). Having a customer's commitment is risky in a sense, as explained above. It also reduces the provider's control of the product, leading to reduced benefit. Then, it appears removing a customer's commitment at all is the best solution. However, it is not the case in general, because it is not always the best from the economic aspect. It should be emphasized that these two factors have a trade-off relation and thus an optimal point should be found. Second, it concerns a closer and longer customer relationship (B4). Having a closer and longer relationship with a customer could make a provider responsible for more. Thus, this risk may be in proportion to this benefit. The provider should determine the 
point where they can take the risk and the benefit.

The type U3 comes from the provider itself. This risk refers to the risk of failures in, for instance, achieving the tasks as planned and includes a failure of service. This has been rarely addressed in the literature and was not explicitly addressed in the case study either.

The last type, U4, is caused by a change of business environment. Especially in the case of result-oriented IPSO, where the provider promises a certain result, this uncertainty can become a risk. For instance, possible change of regulations is a risk if it prevents the provider from keeping the promise. In the studied case, this became a reality; due to the change of environmental regulations, the JV had to change the specification.

\section{Concluding discussion}

As presented in Section 4, the article uncovered benefits and uncertainties that may lead to risks associated with information flow and uncertainty for IPSOs based on the proposed framework, termed the PCP triangle. Some types of benefits and risks were presented in earlier literature, while others are explicitly pointed out in this article, such as the benefit of keeping IPR within the provider and the risk of change of business environment. IPR is one appropriability mechanism that could be used for protecting the technology from being imitated. However companies need to find strategies that are suitable to their specific context making it possible to exploit new possibilities while also securing a protective barrier (Hurmelinna-Laukkanen and
Puumalainen 2007). Other mechanisms are, for example, contracts, secrecy, access possibilities, human resource management strategies (Hurmelinna-Laukkanen and Puumalainen 2007). In the studied case, it is interesting to notice that the JV uses the IPSO as an appropriability regime strategy, enabling the JV to encapsulating the technology and the knowhow, limiting the risk for imitation at the same time as it gets new technology out to the market.

Notably, this article is one of the first that explicitly discusses the IPR issue together with new technologies in an IPSO context, and thus provides IPSO research with a new perspective. The findings are in line with (Lay, Copani, et al. 2010), who argue that the innovativeness of products have positive influences on service integration. In addition, they are in line with (Hypko, Tilebein, et al. 2010), who state that a highly innovative technical solution is suitable for total solution selling as it would be a high risk for a customer to invest in. Yet, the article's value exists in the evidence found in the studied and described case, i.e. that an IPSO is regarded as a positive contributor by practitioners to innovation by testing a new technology with more ease, even in the case with a risk of the technology being copied. In other words, this case study contributes to further establishing the insight by grounding it in a set of events and reasons for decisions made in a real-life setting.

The additional value of this article lies in the theoretical and generic framework. This framework enabled the mutually exclusive classification of risks and benefits. This sound way of classifying risks contributes to the better 
understanding of risks, which leads to better risk management. In addition, the framework can facilitate efficient identification of newly found IPSO benefits and risks in future research. Furthermore, an advantage of this framework is its ease to understand, partly due to its visualization, which is crucial to disseminate insight to practitioners in industry.

The PCP triangle captures information flow and uncertainty of the provider, customer, and product as well as the business environment to model reality. This is also the result of modelling the fundamental source of risks and benefits. Obviously, it may be possible to develop other frameworks by capturing e.g. the cash flow. The proposed framework does not explicitly represent e.g. cash flow by prioritizing representation of the fundamental information.

Shedding light on the environmental aspect in the case study, the case showed an interesting risk for providers of environmental technologies. In general, there is a need for a turn-key solution in environmental technology business (Swentec 2009). In addition, PSS has the potential to better realize environmental performance, especially in result-oriented service (Tukker 2004). These particularly support result-oriented service to gain an environmental benefit from both the business and scientific perspectives. However, this case study uncovered a risk for an environmental technology being highly influenced by environmental regulations. Note that environmental regulations receive increasing attention in general and may be subject to a sudden change in a country like China. This is a pitfall for IPSOs selling environmental performance.

In conclusion, this article proposed a generic framework to present and classify benefits and risks of IPSOs. Although the case study was adopted to gain empirical evidence about a manufacturer of a product with a highly innovative technology, results from the literature review complemented other types of risks and benefits than those identified from the case. Therefore, the framework as well as the risks and benefits are generally valid.

Future work will include developing a method for the integrated analysis of benefits and risks. This article showed some examples of balancing risks and benefits, either in generic terms or in the case study. However, considering the importance of balancing the two, a comprehensive analysis is motivated and its feasibility is foreseen thanks to the PCP triangle - used both for risks and benefits. Additional future research will focus on developing a method of operation for information flow and uncertainty to gain the optimum balance of risks and benefits.

\section{Acknowledgment}

The authors would like to thank the anonymous companies for providing the study with invaluable data. Furthermore, support in data collection and discussion by Ms. Ailin Abdullah and Dr. Jenny Janhager Stier at the Royal Institute of Technology, Sweden, is acknowledged. Finally, the anonymous referees are acknowledged for their help to improve the quality of the paper. 


\section{References}

[1] Alonso-Rasgado, T., Thompson, G. and Elfstrom, B. (2004). The design of functional (total care) products. Journal of Engineering Design, 15(6): 515-540

[2] Aurich, J. C., Fuchs, C. and Wagenknecht, C. (2006). Life cycle oriented design of technical product-service systems. Journal of Cleaner Production, 14(17): 1480-1494

[3] Baines, T. S., Lightfoot, H. W., Evans, S., Neely, A., Greenough, R., Peppard, J., Roy, R., Shehab, E., Braganza, A., Tiwari, A., Alcock, J. R., Angus, J. P., Bastl, M., Cousens, A., Irving, P., Johnson, M., Kingston, J., Lockett, H., Martinez, V., Michele, P., Tranfield, D., Walton, I. M. and Wilson, H. (2007). State-of-the-art in product-service systems. Proceedings of the Institution of Mechanical Engineers - B, 221: 1543-1552

[4] Berger, C. R. and Chaffee, S. H. (eds.) (1987). Handbook of communication science. Sage, Newbury Park, CA

[5] Chesbrough, H. W. (2003). Open innovation: The new imperative for creating and profiting from technology. Harvard Business School Press, Boston, MA

[6] Davies, A. (2004). Moving base into high-value integrated solutions: A value stream approach. Industrial and Corporate Change, 13(5): 727-756

[7] Eisenhardt, K. M. (1989). Building theories from case study research. Academy of Management Review, 14(4): 532-550

[8] Eisenhardt, K. M. and Graebner, M. E. (2007). Theory building from cases:
Opportunities and challenges. Academy of Management Journal, 50(1): 25-32

[9] Fischer, T., Gebauer, H., Gregory, M., Ren, G. and Fleisch, E. (2010). Exploitation or exploration in service business development?: Insights from a dynamic capabilities perspective. Journal of Service Management, 21(5): 591 - 624

[10]Gebauer, H., Fleisch, E. and Friedli, T. (2005). Overcoming the service paradox in manufacturing firms. European Management Journal, 23(1): 14-26

[11]Gebauer, H., Krempl, R. and Fleisch, E. (2008). Service development in traditional product manufacturing companies. European Journal of Innovation Management, 11(2): 219-240

[12]Goedkoop, M. J., Halen, C. J. v., Riele, H. R. t. and Rommens, P. J. (1999). Product service systems, ecological and economic basics. Dutch Ministry of Housing, Spatial Planning and the Environment, Hague

[13]Goh, Y. M. and McMahon, C. (2009). Improving reuse of in-service information capture and feedback. Journal of Manufacturing Technology Management, 20(5): 626-639

[14]Håkansson, H. and Laage-Hellman, J. (1984). Developing a network r\&d strategy. Journal of Product Innovation Management, 4: $224-237$

[15]Hara, T., Arai, T. and Shimomura, Y. (2009). A CAD system for service innovation: Integrated representation of function, service activity, and product behaviour. Journal of Engineering Design, 20(4): 367-388 
[16]Hurmelinna-Laukkanen, P. and Puumalainen, K. (2007). Nature and dynamics of appropriability: Strategies for appropriating returns on innovation. R\&D Management, 37(2): 95-112

[17]Hypko, P., Tilebein, M. and Gleich, R. (2010). Benefits and uncertainties of performance-based contracting in manufacturing industries - an agency theory perspective. Journal of Service Management, 21(4): 460-489

[18]Hypko, P., Tilebein, M. and Gleich, R. (2010). Clarifying the concept of performance-based contracting in manufacturing industries: A research synthesis. Journal of Service Management, 21(5): 625 - 655

[19] Isaksson, O., Larsson, T. C. and Öhrwall Rönnbäck, A. (2009). Development of product-service systems: Challenges and opportunities for the manufacturing firm. Journal of Engineering Design, 20(4): 329 348

[20] Kindström, D. and Kowalkowski, C. (2009). Development of industrial service offerings: A process framework. Journal of Service Management, 20(2): 156-172

[21] Lay, G., Copani, G., Jäger, A. and Biege, S. (2010). The relevance of service in european manufacturing industries. Journal of Service Management, 21(5): 715-726

[22] Lindahl, M., Sakao, T. and Öhrwall Rönnbäck, A. (2009). Business implications of integrated product and service offerings. In: R. Roy and E. Shehab (eds.), 1st CIRP IPS2 Conference, 165-172, Cranfield, April 1-2, 2009, Cranfield University Press
[23] Manzini, E. and Vezzoli, C. (2003). A strategic design approach to develop sustainable product service systems: Examples taken from the 'environmentally friendly innovation' italian prize. Journal of Cleaner Production, 11(8): 851-857

[24] Meier, H., Roy, R. and Seliger, G. (2010). Industrial product-service systems - IPS ${ }^{2}$. CIRP Annals Manufacturing Technology, 59(2): 607-627

[25] Meijkamp, R. (2000). Changing consumer behavior through eco-efficient services: An empirical study on car sharing in the netherlands. Dissertation. Delft University of Technology

[26] Mont, O., Singhal, P. and Fadeeva, Z. (2006). Chemical management services in sweden and europe: Lessons for the future. Journal of Industrial Ecology, 10(1/2): 279-292

[27] Mont, O. K. (2002). Clarifying the concept of product-service system. Journal of Cleaner Production, 10(3): 237-245

[28] Ng, I. C. L. and Nudurupati, S. (2010). Outcome-based service contracts in the defence industry - mitigting the challenges. Journal of Service Management, 21(5): 656-674

[29] Nordin, F., Kindström, D., Kowalkowski, C. and Rehme, J. (2011). The risks of providing services: Differential risk effects of the service-development strategies of customisation, bundling, and range. Journal of Service Management, 22(3): 390 - 408

[30] Öhrwall Rönnbäck, A., Janhager, J. and Abdullah, M. A. (2010). Enhancing the prospects for entering emerging markets via 
business networks. Paper presented at the XXI ISPIM Conference, Bilbao, June 6-9, 2010

[31] Oliva, R. and Kallenberg, R. (2003). Managing the transition from products to services. International Journal of Service Industry Management, 14(2): 160-172

[32] Pender, S. (2001). Managing incomplete knowledge: Why risk management is not sufficient? International Journal of Project Management, 19(2): 79-87

[33] Perks, H. (2004). Exploring processes of resource exchange and co-creation in strategic partnering for new product development. International Journal of Innovation Management, 8(1): 37-61

[34] Sakao, T., Napolitano, N., Tronci, M., Sundin, E. and Lindahl, M. (2008). How are product-service combined offers provided in germany and italy? - analysis with company sizes and countries -. Journal of Systems Science and Systems Engineering, 17(3): 367-381

[35] Sakao, T., Ölundh Sandström, G. and Matzen, D. (2009). Framing research for service orientation through pss approaches. Journal of Manufacturing Technology Management, 20(5): 754-778

[36] Sakao, T., Paulsson, S. and Müller, P. (2011). Integrated evaluation of a PSS business case and a PSS design method application of the PSS layer method to an industrial drilling solution. In: J. Hesselbach and C. Herrmann (eds.), 3rd CIRP IPS2 Conference, 153-158, Braunschweig, May 5-6, 2011, Springer
[37] Sakao, T. and Shimomura, Y. (2007). Service engineering: A novel engineering discipline for producers to increase value combining service and product. Journal of Cleaner Production, 15(6): 590-604

[38] Sakao, T., Shimomura, Y., Sundin, E. and Comstock, M. (2009). Modeling design objects in CAD system for service/product engineering. Computer-Aided Design, 41(3): 197-213

[39] Sawhney, M., Balasubramanian, S. and Krishnan, V. V. (2004). Creating growth with services. MIT Sloan Management Review, 45(2): 35-43

[40] Swentec (2009). Rapport till regeringen maj 2009 - Vägen mot en effektiv struktur för svensk miljöteknik (Report to the Government on May 2009 - Towards an efficient structure for Swedish environmental technology), in Swedish

[41] Teece, D. J. (2007). Explicating dynamic capabilities: The nature and microfoundations of (sustainable) enterprise performance. Strategic Management Journal, 28(13): 1319-1350

[42] Tien, J. M. (2012). The next industrial revolution: Integrated services and goods. Journal of Systems Science and Systems Engineering, 21(3): 257-296

[43] Tukker, A. (2004). Eight types of product-service system: Eight ways to sustainability? Experiences from suspronet. Business Strategy and the Environment, 13: $246-260$

[44] Tukker, A. and Tischner, U. (eds.) (2006). New business for old Europe. Greenleaf Publishing, Sheffield 
[45] Tukker, A. and Tischner, U. (2006). Product-services as a research field: Past, present and future. Reflections from a decade of research. Journal of Cleaner Production, 14(17): 1552-1556

[46] Vargo, S. L. and Lusch, R. F. (2004). Evolving to a new dominant logic for marketing. Journal of Marketing, 68(1): $1-17$

[47] von Hippel, E. (2005). Democratizing innovation. MIT Press, Cambridge, MA

[48] von Hippel, E. and Katz, R. (2002). Shifting innovation to users via toolkits. Management Science, 48(7): 821-833

[49] Wheelwright, S. C. and Clark, K. B. (1992). Revolutionizing product development: Quantum leaps in speed, efficiency, and quality. Free Press, New York

[50] Windahl, C., Andersson, P., Berggren, C. and Nehler, C. (2004). Manufacturing firms and integrated solutions: Characteristics and implications European Journal of Innovation Management, 7(3): 218-228

[51] Windahl, C. and Lakemond, N. (2006). Developing integrated solutions: The importance of relationships within the network. Industrial Marketing Management, 35: $806-818$

[52] Yin, R. K. (1989). Case study research, design and methods. Sage Publications, Newbury Park

Tomohiko Sakao has been professor at Division of Environmental Technology and Management, Department of Management and Engineering, Linköping University, Sweden since 2007. Has been a visiting researcher at the University of Tokyo and at Technical University of Berlin since 2002 and 2009, respectively. Earned Ph. D. from Department of Precision Machinery Engineering, the University of Tokyo, in 1998. His focus at present is environmental and economic sustainability in manufacturing industries. His approaches include Ecodesign and Integrated Product Service Engineering. Served as a lecturer for a dissemination program for environmental business run by METI (Ministry of Economy, Trade, and Industry), Japan in 2004/5. Was awarded a research fellowship by the Humboldt Foundation, Germany to stay at Darmstadt University of Technology from 2005 to 2007, as well as the Young Scientists' Prize by the Commendation for Science and Technology by Minister of Education, Culture, Sports, Science and Technology, Japan in 2009.

Anna Öhrwall Rönnbäck is Associate Professor at the Division of Industrial Economics and Management, the Department of Management and Engineering, Linköping University, Sweden. With a background from industry, as development engineer and project manager, in 2002 she received her $\mathrm{PhD}$ in Industrial Economics and Management from the International Graduate School of Management and Industrial Engineering (IMIE) at Linköping University. Research areas include collaborative product development and technology-based business development, especially for small and medium-sized enterprises (SMEs). This is also her area for teaching master students. She is also a business consultant and member of company boards. 
Since 2007 she is Director of the Center for Applied Management for SMEs at Linköping University.

Gunilla Ölundh Sandström is Associate Professor at the unit of Integrated Product Development, Department of Machine Design, School of Industrial Engineering and Management at KTH Royal Institute of Technology, Stockholm, Sweden. Her research interest is in sustainability and innovation management in technology intensive companies. Research regards Integrated Product Service Engineering having a product- and business development perspective related to both innovation and sustainability. Research also includes aspects of innovation management such as for example how companies increase innovation capability and manage the duality of performing both incremental and radical innovation. Her teaching is within both integrated product and service engineering and product innovation and she is responsible for a master program in Product Innovation. 